黒 田 聖 治*1

\title{
Thermal Spray Technology - A Short Review on the Coating Formation and Structure-property Relationship
}

\author{
Seiji KURODA*1 \\ ${ }^{* 1}$ Hybrid Materials Center, National Institute for Materials Science, 1-2-1, Sengen, Tsukuba, Ibaraki, 305-0047 Japan
}

(Received March 19, 2009, Accepted May 9, 2009)

\begin{abstract}
Thermal spray is defined as a process, in which feedstock materials are heated to a molten or semi-molten state by either electrical or combustion energy and projected in a form of droplets toward a substrate. On the substrate, sprayed particles are flattened and rapidly quenched to solidify to form coatings with peculiar lamellar structures. In this article, a short introduction of thermal spray technology has been given, covering topics such as the principles of thermal spraying process, fundamental processes in coatings formation, structural characteristics of thermal sprayed coatings, and recent developments in the feedstock materials and spray processes. Emphasis was given to deformation and solidification processes of single sprayed particles, microstructure-property relationships of sprayed coatings, and stress generation in coatings.
\end{abstract}

\section{はじめに}

本小特集中の製品紹介でも詳しく説明されるように，近 年, 半導体, フラットパネルディスプレイ (FPD), 太陽電 池等の製造に用いられる真空装置において溶射皮膜の適用が 拡大し定着しつつある. 筆者の知る限りでは主な目的は二つ あり，一つはプラズマや腐食性ガスに対する耐食性付与で皮 膜材料は酸化物である. 他の目的は真空装置の内壁表面に多 孔質の金属皮膜を形成し, エッチングや蒸着によって壁面に 降り積もる堆積物が真空チャンバー中に再放出されるのを防 ぐことであり，皮膜材料は金属である。また，FPD 用のガ ラスの搬送等に使われる静電チャックへの溶射セラミック皮 膜の実用も進んでいると聞く.

溶射技術は発明されてから約100年の歴史があるが，今日 も材料とプロセスの両面で活発に進化を続けている. 本解説 では溶射技術の概要と現状を短時間で把握したいという読者 のために成膜の原理と皮膜の構造や特徵について分かりやす く記述する. 詳しくは成書やハンドブックなどが多数あるの で参照されたい1,2).

\section{1. 溶射プロセスの原理}

溶射とは，「燃焼又は電気エネルギーを用いて溶射材料を 加熱し, 溶融又はそれに近い状態にした粒子を素地に吹き付 けて皮膜を形成する」という表面処理技術である3).下記の 特徵を有するため工業的に広く利用されている.

・加熱により溶融もしくは軟化する材料ならば，ほとんどあ らゆる材料（金属, セラミックス, プラスチック, 複合材 料）の皮膜を生成できる.

・ 10 ミクロン以上の液滴や粒子が皮膜生成の単位であるた め, CVD や PVD 等の蒸着型のコーティングプロセスに 比べて皮膜の生成速度が格段に高い.

・冷却等の温度管理をすることにより，金属はもとより，プ

*1 物質・材料研究機構ハイブリッド材料センター
ラスチックや紙など多種類の材料の上に皮膜生成が可能で ある・

・溶射ガンや被覆対象物を適宜動かすことにより, 複雑形状 や大面積の部材に適用可能である.

・フレーム溶射やアーク溶射等, 溶射方式によっては現場施 工が可能である.

\section{1 基材前処理}

他の成膜プロセスと同様, 溶射においても基材前処理は皮 膜の密着性の確保のために重要である. 溶射皮膜の密着機構 は完全には解明されてはいなが，一般には投射される溶射粒 子と基材との間に治金的な結合が生じる場合は少なく，濡れ 性や機械的噛み合い（アンカーリング）が密着性を支配する 重要な因子と考えられている. 従って, 基材の前処理として 表面の清浄化と適度な粗面化が行われる. 具体的な手段は基 材の種類や表面状態によって異なるが, 金属基材の場合, 除 錆処理と粗面化処理を兼ねてグリットブラスチングが行われ る場合が多い，用いられるグリット材は各種あるが，スチー ルグリット，アルミナグリットなどが一般的である．近年は 環境への配慮等の視点からレーザ，ウォータージェットやド ライアイスによるクリーニング処理も検討されている. どの ような前処理を行った場合でも，できるだけ時間をおかずに 次の溶射プロセスに進むことが推奨されている.

\section{2 溶射}

溶射では皮膜の原料を何らかの熱源によって溶融・半溶融 の状態に加熱し, 微細な溶射粒子の状態として基材に投射し て積層 ·凝固させて膜を形成する. 熱源の種類, 原料の形態 によって概略, Fig. 1 のように分類される. 開発の歴史を 巡れば初期の1910年代に開発・実用化されたのがフレーム 溶射とワイヤーアーク溶射であり, フレーム溶射では酸素・ アセチレン炎などのフレーム中に原料粉末，あるいはワイ ヤーが供給されて溶融し，基材に向かって投射される．Fig. 2 はワイヤーアーク溶射の原理図で, 原料となる一対の金属 ワイヤー（線材）間にアーク放電を発生させ，その熱によっ て先端を溶融させる. 発生した溶融液滴を後方から供給され 


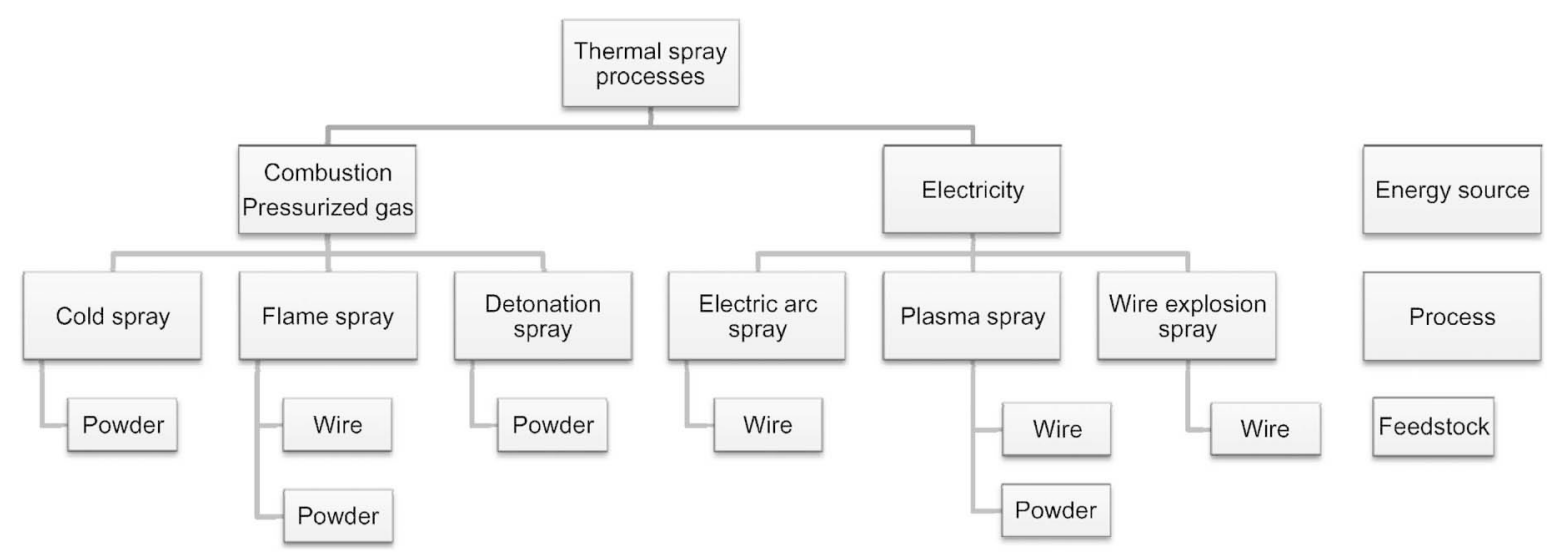

Fig. 1 Classification of thermal spraying processes.

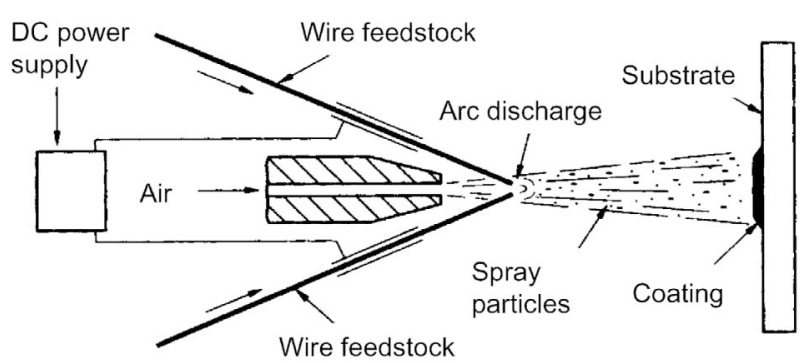

Fig. 2 Principles of wire arc spraying (Excerpted from A. Hasui, Yousha Kougaku).

るガス流によって分裂させ基材に対して投射させる．消耗分 のワイヤーが自動的に供給されるので連続的に溶射液滴が発 生する.このプロセスはエネルギー効率が高く, ワイヤー原 料も粉末に比較して経済的であるので, 橋梁などの大型構造 物に対して特に有効なプロセスである.

その後1960年代から Fig. 3 に示すプラズマ溶射が開発さ れた. プラズマ溶射では, タングステン陰極と水冷銅の陽極 間にアーク放電を発生させ, アルゴン等の不活性ガスを主成 分とするガスを熱プラズマ状態にまで加熱する，その結果， プラズマ化したガスは著しい体積膨張のために高速度の噴流 （プラズマジェット）となってノズルから噴出する。この中 に原料となる粉末を供給して加熱・溶融して基材上に投射す るのがプラズマ溶射の原理である．熱源となるプラズマジェ ットの温度が 1 万 K を超える超高温であることから酸化物 や高融点金属などの高融点材料の溶射が可能となり, ジェッ トエンジンの高温部品などへの適用が格段と進んだ。また， 大気中で溶射すると原料金属の酸化が問題となる場合には, 不活性減圧雾囲気中で溶射を行う減圧プラズマ溶射も実用さ れている. 80年代には高速フレーム (High Velocity Oxyfuel: HVOF) 溶射が開発・実用化された。このプロセスは 燃焼炎を用いる点でフレーム溶射の一種であるが，燃焼室の ガス圧力が高く, ロケットノズルと類似の構造によってフ レームジェットの速度を $1000 \mathrm{~m} / \mathrm{s}$ 以上に高めている点に特 長がある. 大気中で金属材料や炭化物サーメットなどを溶射 する場合, プラズマ溶射では材料の酸化や劣化が著しい場合 が多いが, HVOF 溶射では熱源の温度が低いために劣化が

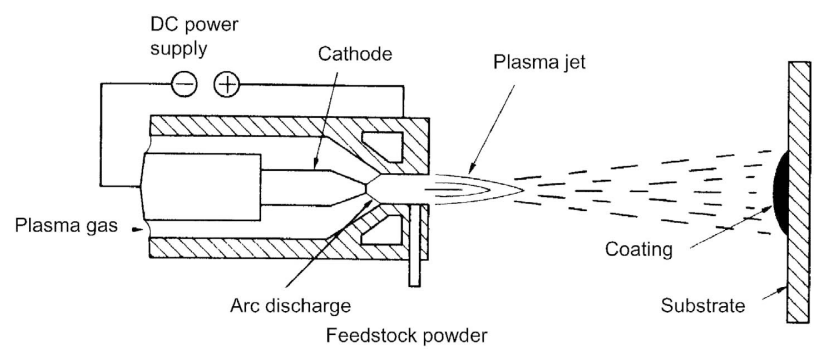

Fig. 3 Principles of plasma spraying (Excerpted from A. Hasui, Yousha Kougaku).
少なく, また粒子速度が高いために皮膜の緻密度が高く密着 性も高い皮膜が得られる場合が多い. WC-Co などの硬質耐 磨耗コーティングの製造に広く実用されている. 近年は, 後 述するようにさらにガス温度を低めたコールドスプレー等の 原料を溶融させないプロセスが開発され, 実用に向けて活発 に研究開発が行わ机ている.

\section{3 後処理}

溶射皮膜の使用目的に応じて後処理が行われる場合があ り, 機械加工, 熱処理, 封孔処理が代表的な処理である. 機 械加工は製鉄, 製紙, 印刷などに用いられるロール関係でよ く行われ, 膜厚を所定厚さにまで研削し, さらに表面を所定 の粗度まで仕上げ研磨する. 熱処理が最も広く行われている のは自溶性合金と呼ばれる $\mathrm{Ni}-\mathrm{Cr}-\mathrm{Si}-\mathrm{B}-\mathrm{C}-\mathrm{Fe}$ を主成分とす る合金溶射皮膜である. 溶射成膜後に合金の固液共存領域 （通常 $1,000^{\circ} \mathrm{C}$ 付近）にまで加熱し, 溶射時に形成して皮膜 中に分散した酸化物をシリコン, ボロンなどのフラックス作 用によって表面に排出させると共に，皮膜を緻密化し基材と の拡散によって密着性を向上させる効果もある4)，組成によ って硬度を調整し, 耐摩耗, 耐食の目的で信頼性の高い皮膜 として用いられている. 封孔処理は防錆及び耐食皮膜で広く 行われる. 溶射皮膜は通常, 多孔質なため樹脂を表面から気 孔に浸透させて封孔し，腐食成分が皮膜中に浸透するのを防 ぐ. 皮膜材料, 使用環境によって種々の封孔剂が用いられ る5).この他, 特殊な後処理として, 印刷機用ロールでは鏡 面研磨後にレーザで規則的なパターンを刻み込むことも行わ れる. 


\section{2. 成膜過程}

\section{1 溶射粒子の衝突 · 扁平 · 凝固過程}

前述したように溶射に用いられる原料はワイヤーまたは粉 末の形態で供給されるが，熱源によって粒子径が $10 〜 100$ ミ クロン程度の溶融液滴になって基材に投射される．原料の供 給速度，すなわち基材への投射量は溶射プロセスによってか なり異なるが $10 \sim 500 \mathrm{~g} / \mathrm{min}$ である. 溶射ガンは, 基材上か ら一定の距離を保ちつつコーティングする面上を均一にカ バーするように走査される，溶射ガンの走査はロボットや簡 易的な走査機構を用いる場合と, 技能者が人力で行う場合が ある.1回の走査でどれほどの膜厚を盛るかは，材料にもよ るが施工上の重要なポイントとなる場合もある．1回の走査 であまり厚く盛りすぎると過熱や酸化の原因となる.

Fig. 4 は溶射粒子が経験する現象の温度履歴をプラズマ 溶射を念頭に概念的に示したものである。粉末粒子は高速 . 高温のプラズマジェットに投入されると数 $\mathrm{ms}$ の間に溶融さ れ融点以上の温度に加熱される，基材へと飛行する間に周囲 のガス温度が大気の影響で低下するために，粒子の温度も低 下するが基材到着時には融点よりも高く，基材に衝突した瞬 間に粒子は扁平して数ミクロンの厚さとなりつつ基材への熱 伝導によって急冷される。この際の冷却速度は種々の計算や 実測によって通常は $10^{6} \mathrm{~K} / \mathrm{s}$ 以上であることが知られてい る. 従っていわゆる急冷凝固が溶射粒子毎に起きている。こ の為に過飽和固溶体，アモルファス，準安定相などの非平衡 組織が現れやすい．また，熱の流れが基材に向かって垂直方 向なので基材垂直方向へ柱状晶組織が発達する場合が多い.

Fig. 5 はプラズマ溶射されたジルコニア溶射粒子が実際 に基材上に衝突する様子を世界で初めて超高速度ビデオカメ ラで撮影した画像である6). フレーム間隔は $1 \mu \mathrm{s}$ で画面右側 から飛来する単一ジルコニア粒子の直径は約 $50 \mu \mathrm{m}$, 飛行速 度は約 $170 \mathrm{~m} / \mathrm{s}$ である. 室温の平滑基材に衝突・変形して大 部分が飛散する様子が捉えられている。この実験では基材が 室温の石英板であり，表面に吸着した水分子等によってジル

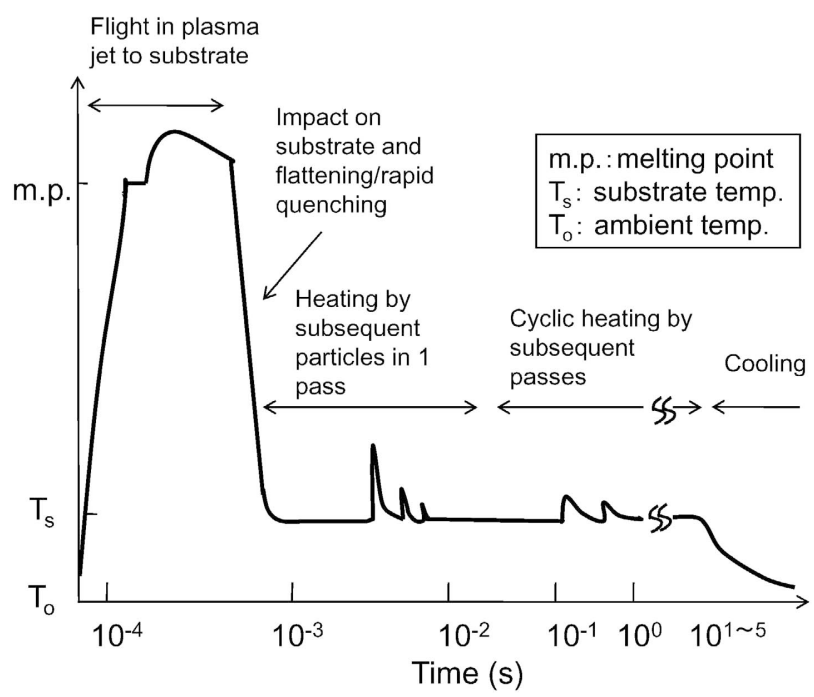

Fig. 4 Schematic diagram of thermal history for a single thermal sprayed particle.
コニアと基材間の濡れ性が悪く, ジルコニアが扁平する途中 で基材から浮き上がっていることが画像から分かる. 基材温 度を上昇させて濡れ性を良くすると基材への熱伝導が向上 し, 扁平途中で凝固によって粒子の飛散が抑制されて円盤状 の付着粒子が形成されることが知られているが，その場合の 映像は未だ撮影できていない。この画像は，溶融粒子を堆積 する溶射において，基材，あるいは皮膜表面での濡れ現象が 溶射粒子/基材間，溶射粒子相互間の密着性に重要なことを 示している.

\section{2 応力発生過程}

溶射皮膜に発生する残留応力は皮膜の密着性やはく離挙動 に影響するために実用上重要な特性である。溶射中の基材の 曲率をその場で連続的に測定することによって応力発生過程 を解析した ${ }^{7)}$.

Fig. 6 は用いた基材曲率装置の原理図で長方形の基材を 一対のナイフエッジ上に固定し，中央部の変位を変位計で測 定する ${ }^{8)}$. 同時に基材裏面にスポット溶接した熱電対によっ て基材温度も測定する. Fig. 7 に代表的な測定例として, タービンエンジンなどの高温部品に耐酸化の目的で施工され る $\mathrm{NiCrAlY}$ 合金を炭素鋼上にプラズマ溶射した際に記録さ れたデータを示す。上側が曲率のデータで皮膜側が凹になる 方向をプラスにとってある。 下が基材温度のデータで，周期 的な変動が溶射ガンの 1 回の通過に対応している。まず溶 射ガンによって基材を約 $200^{\circ} \mathrm{C}$ まで予熱後, 粉末を供給して
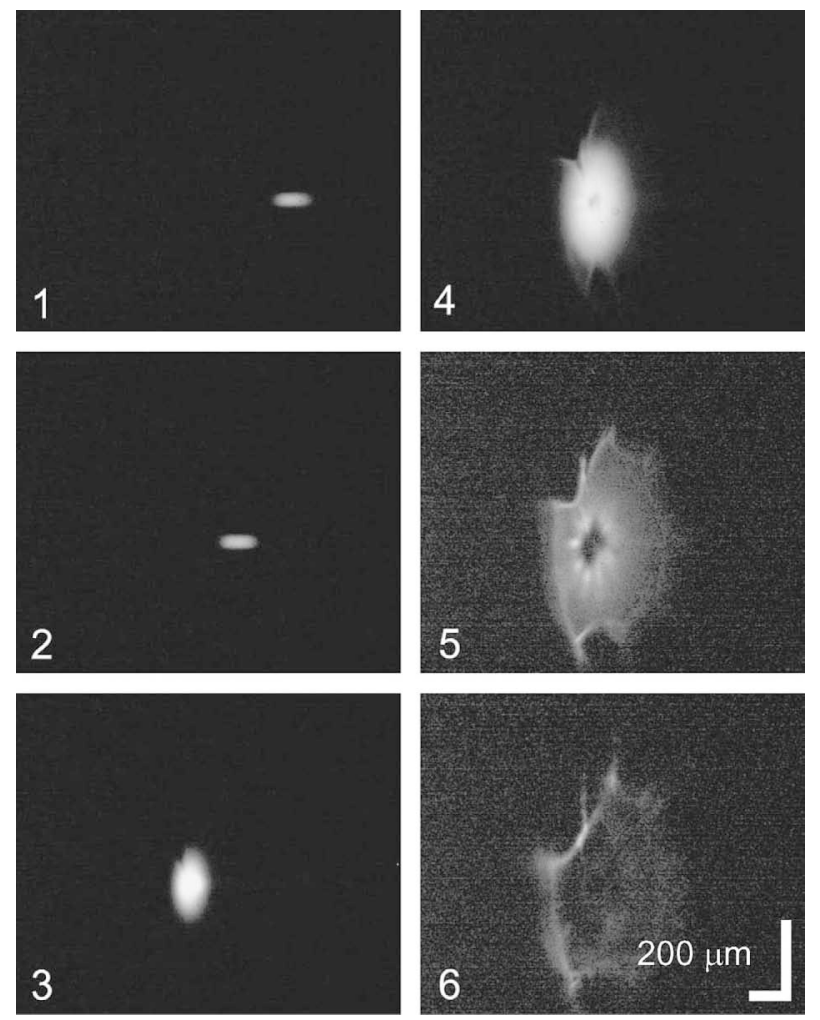

Fig. 5 Ultra-high speed video images of a single impact of thermal sprayed particle captured at 1 million frames/s. A zirconia particle with $50 \mu \mathrm{m}$ diameter flying at $170 \mathrm{~m} / \mathrm{s}$ enters the field of view from right (1-2), spreads and flattens on a flat substrate at room temperature (3-6) and disintegrates finally. 
成膜を開始した. 成膜中，基材は皮膜側が凹になる方向に一 定の割合で変形していくことが分かる.これは，基材上に堆 積した溶射粒子が急冷されて凝固後に基材温度にまで冷却す る際に，熱収縮しようとするが基材に拘束されるために粒子 内に引っ張りの応力が発生することを示している．この応力 は急冷応力と呼ばれ，プラズマ溶射のように溶射粒子が溶融 しているプロセスでは必ず引っ張り応力になる. 溶射終了 後, 皮膜と基材が一体化した試験片の温度は室温まで下がる が，この皮膜と基材の組み合わせの場合には両者の熱膨張係 数が近いために大きな曲率変化は発生しなかった.

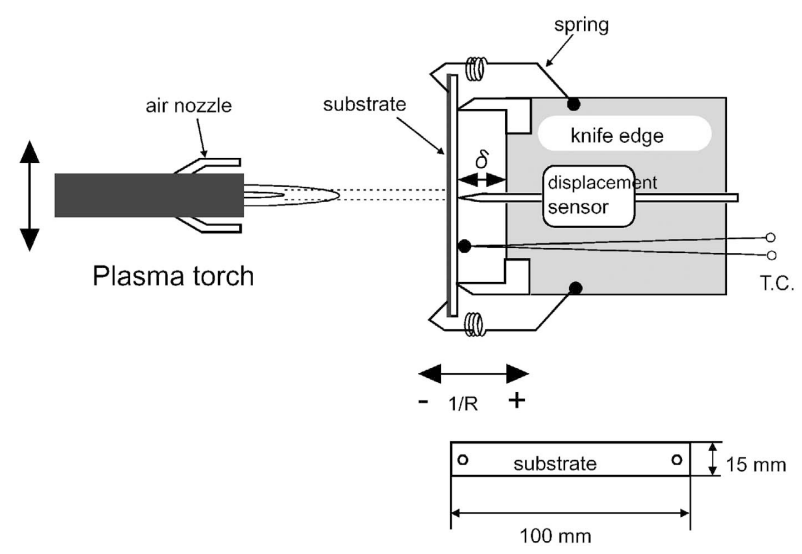

Fig. 6 Schematic of in-situ curvature monitoring instrument used during thermal spraying.
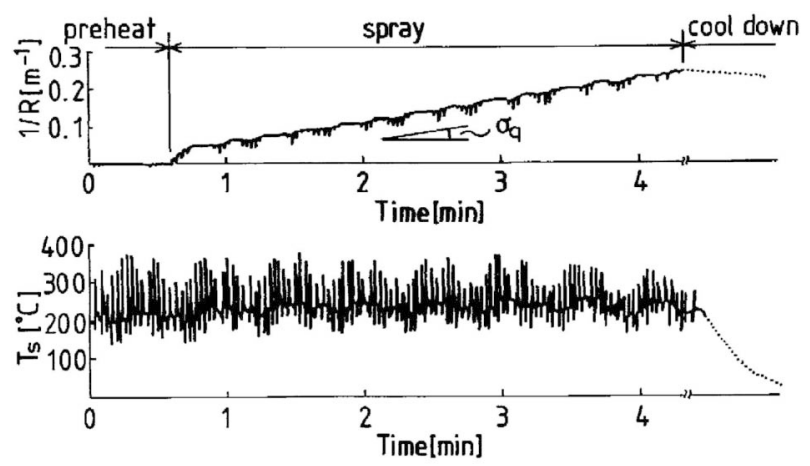

Fig. 7 An example of measured curvature during thermal spraying. (Coating: NiCrAlY alloy, substrate: carbon steel)
Fig. 8 にモリブデンとアルミニウムを炭素鋼基材上にプ ラズマ溶射した場合の曲率変化を異なる基材温度の場合につ いて示す. 溶射終了後の曲率変化が Mo の場合には基材の収 縮の方が大きいために負（圧縮）方向に, $\mathrm{Al}$ の場合には逆 の正 (引張り) 方向になる事が分かる. つまり, 成膜後の応 力発生はバイメタルと同様に皮膜と基材の熱膨張差によって 支配されている，これらのことから，溶射皮膜の残留応力は 成膜中の急冷応力と, 成膜後の冷却中の熱応力の重ね合わせ たものと考えられる. Fig. 9 は各種皮膜材料について, 溶 射中の基材曲率の変化率から計算された急冷応力の基材温度 依存性をまとめたグラフである. 急冷応力は高温強度が高い 材料ほど高い值を示す傾向があり, 純 $\mathrm{Ni}$ よりも $\mathrm{Ni}-20 \mathrm{Cr}$ の 方が顕著に高い值となる。 また, 基材温度をある程度までは 高くした方が高い応力が発生する傾向があり，これは溶射粒 子間の密着性が高まるためと推測される. しかし, 基材温度 が皮膜材料の融点に近くなると皮膜材料自体が軟化するため に急冷応力の值は低下する. また, セラミック材料は一般に かなり小さい急冷応力を示すが，これは急冷時に粒子中にミ クロクラックが発生して, 応力が大部分開放されてしまうた めである. Fig. 10に平滑基材上に付着した代表的なプラズ マ溶射粒子の形態（(a) Ni-20Cr，（b）ジルコニア）と急冷応 力発生の模式図を示した. 従って酸化物等のセラミック皮膜 の残留応力は, 成膜後の熱応力が支配する傾向が強い。こう した知見を利用すれば，皮膜材料と基材材料の組み合わせや

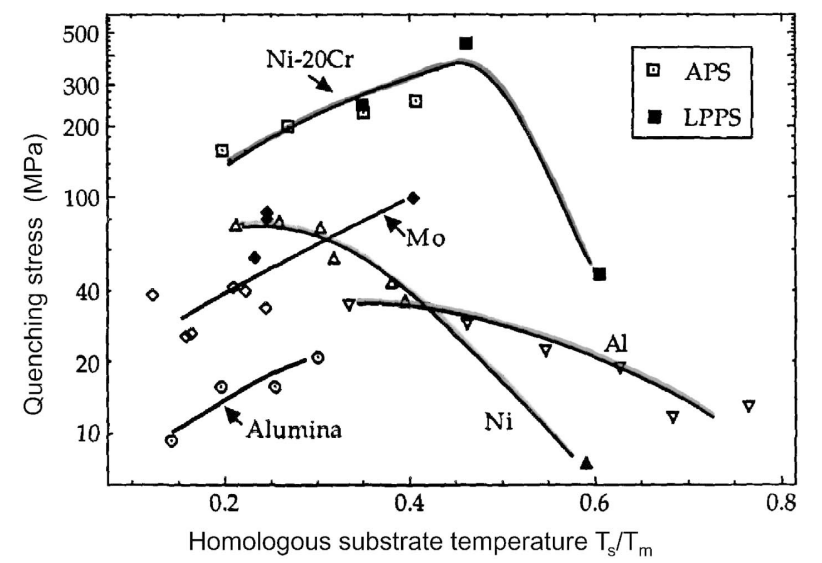

Fig. 9 Dependence of quenching stress on homologous substrate temperature.

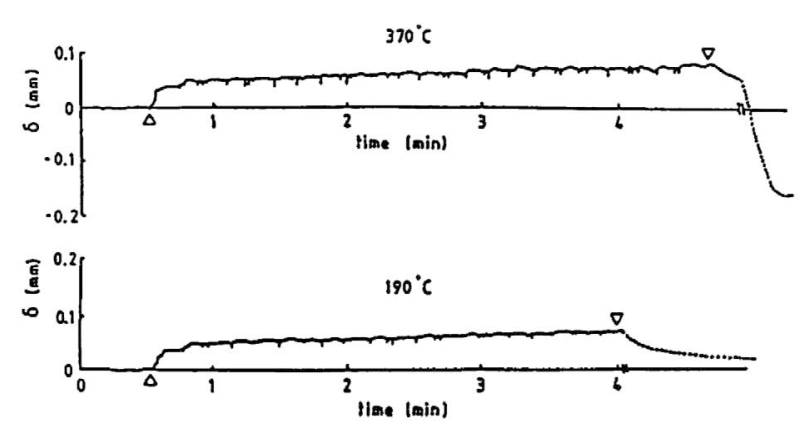

Mo

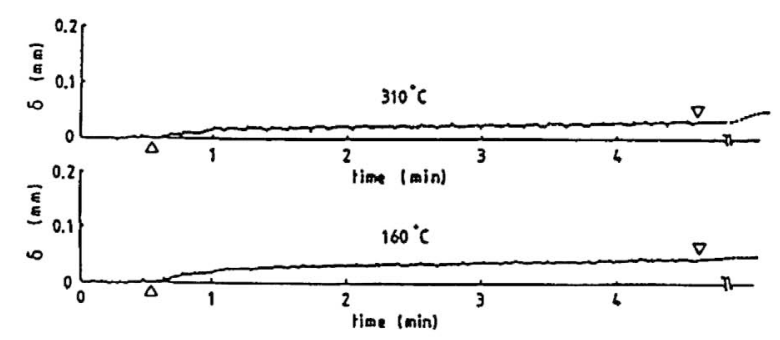

Al

Fig. 8 Effects of coating materials $(\mathrm{Mo}, \mathrm{Al})$ and substrate temperature on the curvature change during thermal spraying. 


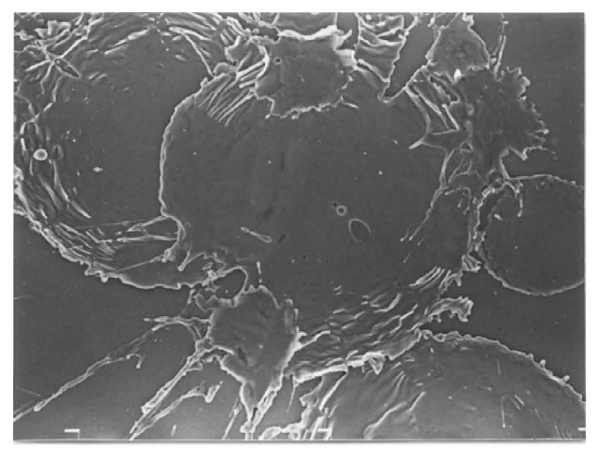

(a)

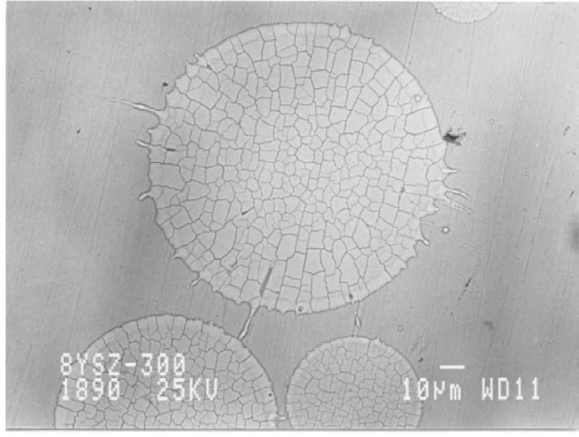

(b)

$50 \mu \mathrm{m}$

Molten particle $10 \sim 100 \mu \mathrm{m}$

$100 \mathrm{~m} / \mathrm{s}$

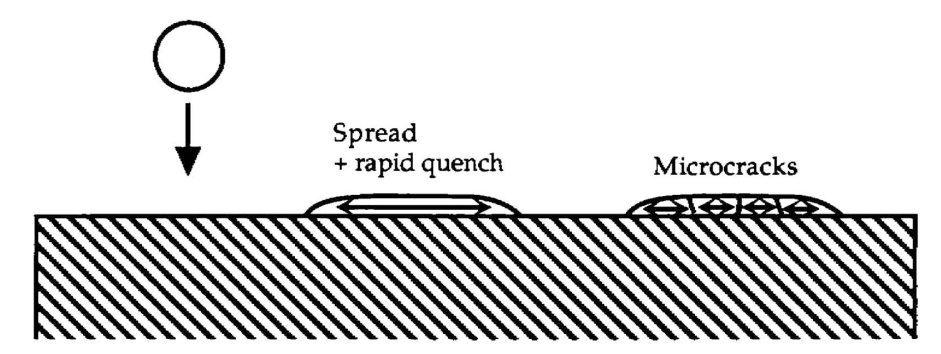

(c)

Fig. 10 Morphology of plasma sprayed particles captured on flat substrates: (a) $\mathrm{Ni}-20 \mathrm{Cr}$, (b) zirconia, and (c) schematic of quenching stress generation.

基材温度に応じて, 残留応力を予測・制御可能である.

\section{3. 皮膜構造の特徵}

\section{1 多孔質と異方性}

溶射皮膜は多孔質であるとよく言われるが，それは溶射皮 膜の特徵の一端を表しているに過ぎない，Fig. 11は縦軸に 多孔質材料のヤング率を, 横軸に気孔率をとし, 計算によっ て求めたヤング率と実測された溶射皮膜のヤング率を比較し た結果である. 図中のパラメータ S は計算に用いた Eshelby 等価介在物モデルで気孔の形態として回転棈円体を仮定して おり，そのアスペクト比を表す． $\mathrm{S}=1$ が球形の気孔で $\mathrm{S} の$ 值が小さくなるほど, 応力方向に垂直な方向に扁平化した形 状を示す．溶射皮膜の特性は球状の気孔率の值から予想され るよりもかなり低く, 非常に強く気孔の形状の影響を強く受 けていると言える.

実際に溶射皮膜中の気孔に他の材料を浸透させて可視化さ せるという方法を用いて調べた. Fig. 12は大気中プラズマ 溶射した $\mathrm{Ni}-20 \mathrm{Cr}$ 合金とアルミナ溶射皮膜の断面反射電子 像で，気孔中には白く見える材料が浸透処理されている. (a) の合金皮膜中には塊状の空孔以外に，層間の未接合部（Interlamellar pore）が，さらに(b)のアルミナ皮膜では縦方向 のミクロクラックが多数存在することが分かる. 層間未接合 部やミクロクラックは, 通常の研磨処理と観察法では見落と す場合も多く，また体積分率という意味では寄与が小さく見 えるが，前図に示したように特性に及ぼす影響は大きいこと に注意しておく必要がある.

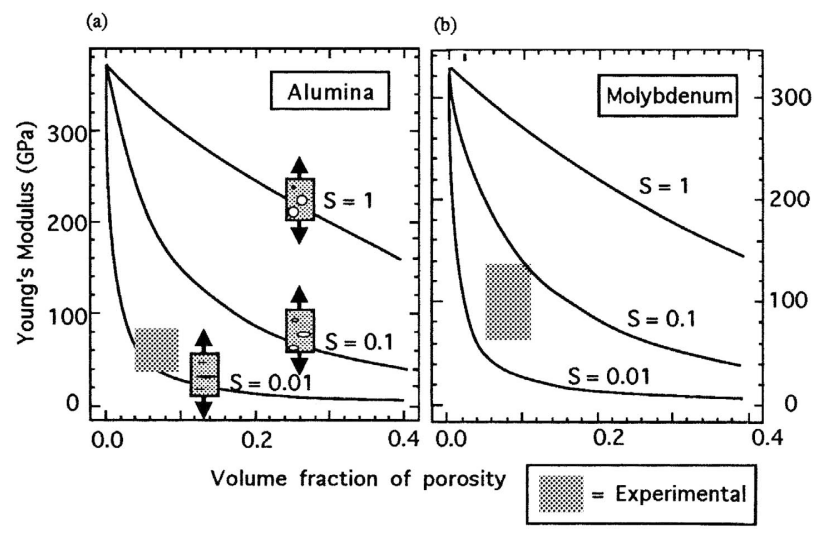

Fig. 11 Calculated elastic moduli of porous alumina and molybdenum by using the Eshelby equivalent inclusion model. S represents the aspect ratio of spheroidal pores. The grey rectangular areas represent measured/reported values of thermal sprayed coatings.

\section{2 急冷凝固}

前述したように, 溶射では一個一個の溶射粒子が急冷凝固 するので, 過飽和固溶体, アモルファス, 準安定相などの非 平衡組織が現れやすい。これらの準安定組織は安定相に比較 して特異で有用な特性を持つ場合もあり, 研究例も報告され ているので興味のある方は参考文献を参照されたい9).

\section{4. 最近の技術動向}

近年の溶射技術の動向として，プロセスと材料の多様化と 


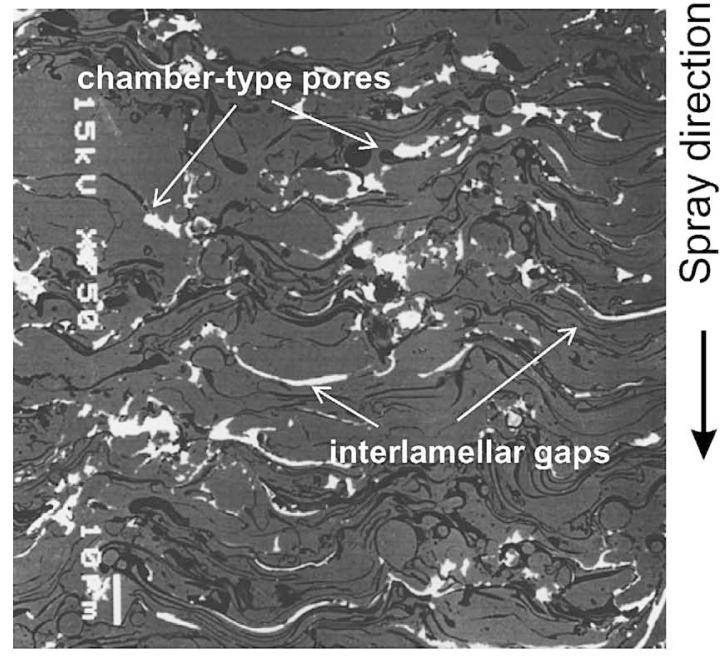

(a) $\mathrm{Ni}-20 \mathrm{Cr}$

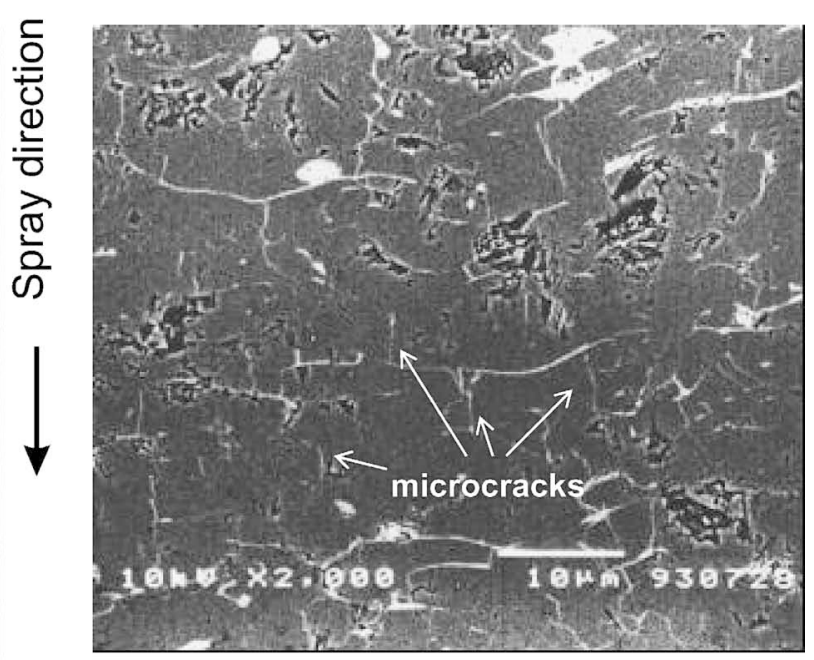

(b) Alumina

Fig. 12 Back scattered electron images of polished cross sections of (a) $\mathrm{Ni}-20 \mathrm{Cr}$ and (b) alumina thermal sprayed coatings. Specimens were impregnated to fill the pores with materials with higher atomic numbers than the coatings.

プロセスの信頼性向上の二つの大きな流れを感じる．プロセ ス面では，コールドスプレーなどの原材料を溶かさない成膜 法が注目されている10)。材料面では液体状の原料をプラズ マや火炎に投入して成膜するサスペンション溶射法が研究段 階ではあるが，従来の酸化物皮膜とはかなり異なる組織の皮 膜が作成可能なことが報告されている11).

プロセスの信頼性向上の面では, 溶射粒子の温度と速度を 同時にモニターする装置がかなり普及してきて抢り, 皮膜組 織の再現性向上に今後, 中心的な役割を果たすものと期待さ れる。 また, 紹介した基材曲率以外にも成膜中の諸現象 (例：アコースティックエミッション）をモニターする技術 の開発も期待される12).

\section{5. まとめ}

溶射皮膜は，一般の消費者がほとんど目にする機会がない 産業機械やエネルギープラント, 化学プラント, エンジンの 内側などで重要な役割を果たしている. 特に発電用タービン や航空機のタービンエンジンなどの効率向上では必須技術と なっており，性能向上のために熾烈な技術開発競争が各国で 行われており, また学術分野からも多数の研究者が参画して いる．真空技術分野でも耐プラズマコーティングにその䕬矢 が認められる. 今後, この分野でも学際的な情報交換と議 論・共同研究の場が広がることを期待したい.

\section{〔文献〕}

1) A. Hasui: Yousha Kougaku (Thermal Spray Technology), Sampo, 1996 [in Japanese].

Y. Arata: Seramikku Yousha (Ceramic Thermal Spraying), (Nikkan Kogyo Shinbun, 1990) [in Japanese].
L. Pawlowski: The Science and Engineering of Thermal Spray Coatings, 2nd Ed., Wiley, 2008.

2) Handbooks, Japan Thermal Spraying Society, Yousha Gijutsu Handbook (Thermal Spray Technology Handbook), 1998 [in Japanese $]$.

S. Kuroda and A. Sturgeon: Thermal Spray Coatings for Corrosion Protection in Atmospheric and Aqueous Environments, ASM Handbook 13B (ASM International), 422-429, 2005.

3) JIS H 8200: 2006, Yousha Yougo (Thermal spraying terms) [in Japanese].

4) JIS H 8303: 2004, Jiyou Goukin Yousha (Spray fused coatings of self-fluxing alloys) [in Japanese].

5) Japan Association for Corrosion Control, Bosei Gijutsu ni kansuru Chousahoukokusho, (A Survey Report on Corrosion Prevention by Thermal Spray), 2002, [in Japanese].

6) K. Shinoda, H. Murakami, S. Kuroda, S. Oki, K. Takehara and G Etoh: High-speed thermal imaging of yttria-stabilized zirconia droplet impinging on substrate in plasma spraying, Appl. Phys. Letters, 90 (2007) 194103.

7) S. Kuroda and T. W. Clyne: The Quenching Stress in Thermally Sprayed Coatings, Thin Solid Films, 200 (1) (1991) 49-66.

8) S. Kuroda, T. Fukushima and S. Kitahara: Simultaneous Measurement of Coating Thickness and Deposition Stress During Thermal Spraying, Thin Solid Films, 164 (1988) 157-163.

9) S. Kuroda: Properties and Characterization of Thermal Sprayed Coatings - A review of Recent Research Progress, Thermal Spray Meeting the Challenges of the 21st Century, Proc. 15th Int. Thermal Spray Conf. May, 1998, Nice, pp. 539-550.

10) A. Papylin et al.: Cold Spray Technology, Elsevier, 2006. V. K. Champagne ed., The Cold Spray Materials Deposition Process: Fundamentals and Applications, Crc Pr I Llc, 2007.

11) P. Fauchais: Suspension and Solution Plasma or HVOF Spraying Suspension and Solution Plasma or HVOF Spraying, J. Thermal Spray Technol., No. 1, 17 (2008) 1-3.

12) K. Ito, M. Enoki, M. Watanabe and S. Kuroda: In situ monitoring of plasma spraying process by laser acoustic emission method, Modern Physics Letters B, 22 (11) (2008) 977-982. 